\title{
New Therapeutic Strategies in Gliomas Treatment
}

\author{
Gerardo Caruso, Mariella Caffo, Giuseppe Raudino, \\ Concetta Alafaci and Francesco Tomasello \\ Neurosurgical Clinic, Department of Neurosciences, Psychiatry and Anaesthesiology \\ University of Messina \\ Italy
}

\section{Introduction}

Gliomas account for about $45 \%$ of all primary central nervous system (CNS) tumors and $77 \%$ of all malignant primary CNS tumors. Gliomas develop from diverse histological lineages, including oligodendrogliomas, astrocytoma and mixed oligoastrocytoma and all have the potential to become highly malignant neoplasms. Recent studies in molecular biology have better depicted the mechanisms involved in the genesis of cerebral gliomas. It is now generally understood that tumor genesis occurs either by over-expression of oncogenes or inactivation of tumor suppressor genes. Cerebral gliomas represent an interesting target for local gene therapy because of its restricted anatomical location and absence of metastases outside the CNS. This allows delivery of vectors directly to the desired site only a small risk of systemic toxicity (Immonen et al., 2004). The two main gene groups involved in brain tumor development are proto-oncogenes and tumor suppressor genes, respectively upregulated and downregulated during the tumor initiation and progression. In these processes are activated growth factors signaling pathways, marked angiogenesis, downregulation of apoptotic genes and upregulation of antiapoptotic genes. The principal proto-oncogenes involved in gliomagenesis encode for growth factors, growth factors receptors, or downstream effectors of growth factors function, including c-sis (PDGFB chain), erb-B (EGFR), ras (second messenger for GFRs) and myc (transcription factor). Other important genes and protein functions involved in brain tumor development are bcl2, protein kinase C-a (PKC- $\mathrm{a})$, c-raf-1, protein kinase A-Type I (PKA I), telomerase, MDM2, IGF I and insulin-like growth factor I receptor (IGF-IR), HER-2 (encoded from c-erbB-2 gene), bFGF, fibroblast growth factor receptor (FGFR), TGF- $\alpha$, TGF- $\beta 2$, vascular endothelial growth factor (VEGF), integrins and genes and proteins involved in the cell cycle control, cell proliferation and programmed cell death, angiogenesis and invasiveness pathways. It's evident that the modulation of gene expression at more levels, such as DNA, mRNA, proteins and transduction signal pathways, may be the most effective modality to downregulate or silence specific genic functions. In addition to tumor-suppressor genes and proto-oncogenes, there are, also, the suicide genes. These last ones encodes for a nonmammalian enzyme, that is used to convert a non-toxic prodrug into its active cytotoxic metabolite within the cancerous cells. 
Cancer gene therapy can be subdivided into two main strategies: immunological and molecular approaches. The first try to overcome the escape of cancer cells from immune system. Despite the initial enphasys of preclinical immune-gene therapy studies, only a few of these modalities have entered into human trials for gliomas treatment. Genetic immunotherapy can be used mainly to boost T-cell mediated immune response against cancer. This approach involves the transfer of the genes of the immune-stimulant molecules, such as cytokines. Interleukin-12 gene is one of the most studied cytokine. It has been showed complete tumor regression in murine cancer models after interleukin-12 gene transfection into hepatocellular carcinoma and adenocarcinoma cells. The production of IL12 by tumor cells, after IL-12 gene transfection, mediates activation of cytotoxic T lymphocytes and natural killer (NK) cells (Wesseling \& Adema, 2009). Direct genetic vaccination by the antigen (tumor-specific antigen)-encoding genes, like transfection of in vitro engineerized dendritic cells with specific antigens, can also induce the desired antitumoral immune reaction (El-Aneed, 2004; Passioura \& Symonds, 2004).

Molecular approaches in cancer gene therapy involve the modulation of oncogenes, tumorsuppressor genes and suicide genes. One of the most investigated suicide gene/prodrug system is the herpes simplex virus thymidine kinase (HSV-tk)/ganciclovir (GCV) system. This indirect gene therapy system has been carried out through the delivery of the herpes simplex virus thymidine kinase (HSV-tk) gene to the tumor by using an adenovirus vector and by transplantating genetically in vitro engineerized cells or inoculation of a recombinant defective virus form into a target cell. Adenoviruses transfer their DNA by binding to a specific cell surface receptor to form a pore in the endosome to translocate genetic materials to the nucleus. The penetration of HSV-tk gene inside only tumoral cells allows the synthesis of thymidine kinase protein and the selective death only of these cells. This process lead to intracellular viral replication and exclusive cytolysis of targeted cancer cells; the newly released virions from a leased cell could infect the neighboring and distant cells but selectively replicate only in cancer cells (Izquierdo et al., 1996). Regarding tumor suppressor genes, because their implication in cancer initiation and progression only when they are deleted in homozygote pattern, the gene therapeutic strategy with should be directed to reach the wild type form of the specific gene function into cancer cell, differently than classic antisense therapy that lead to silence specific genic sequences, usually mutated and/or amplified oncogenes through inhibitors small RNA or DNA molecules.

The prognosis for patients affected by brain tumors is influenced by the histological features of the neoplasm, the age of the patient and the neurological condition or functional status. Despite progresses in microneurosurgical approaches, radiotherapy, radiosurgery and chemotherapy as well as in experimental immunotherapy an effective curative treatment of gliomas does not yet exist. Mortality, in particular if considered into high-grade gliomas cohort, is still close to $100 \%$ and the average survival of patients with glioblastoma multiforme (GBM) is less than 1 year when classical treatments is used (Gonzalez \& Gilbert, 2005; Stupp et al., 2005). Indeed, progress in treatment of this disease has led only to a slight increase in average survival up to 15-18 months. The efficacy of current anti-cancer strategies in gliomas is limited by the lack of specific therapies against malignant cells. The blood brain barrier limits, moreover, the delivery of many chemotherapeutic agents to the central nervous system, contributing to the failure of treatment. An increased site specificity and internalization can improve the efficacy of treatment and decrease the possibility of side effects. 
A potential and futurible therapeutic approach in gliomas treatment is represented by antisense therapy to block selectively glioma cells, trying to led to revert gliomagenetic molecular pathways. This aim could be reached through antisense molecules, delivered inside the brain and in particular inside tumoral cells, able to penetrate into glioma cells nucleus and to integrate with their genome to silence some specific genic functions. Among antisense molecules there are antisense oligonucleotides, ribozymes and RNA interference (iRNA). The specificity of hybridization makes antisense method an interesting strategy to selectively modulate the expression of genes involved in tumorigenesis. Glial tumors seems to be able to create a favorable environment for the invasion of glioma cells in cerebral parenchyma when they combine with the extracellular matrix (ECM) via cell surface receptors. In clinical oncology there are various interesting examples regarding the efficacy of anticancer antisense therapy. Rubenstein et al. published a very interesting findings in an in vivo murin model of human PC-3 prostate tumor. The intralesional injection of antisense oligonucleotides directed against mRNA encoding TGF- $\alpha$ and its target, EGFR, reached to an important hemorrhagic necrosis inside the tumor, directly correlated with cancer cell death. Moreover, although direct intratumoral injection of antisense oligonucleotides was effective, systemic administration appeared to have a better response rate (Rubenstein et al., 1996). Similar results have been obtained from Smythe et al. in malignant pleural mesothelioma lines REN (epithelial) and 1-45 (sarcomatous), using modified bcl-xl antisense oligonucleotides directed near the mRNA initiation sequence. This approach induced upregulation of apoptosis in mesothelioma cell lines (Smythe et al., 2002). In this chapter we describe the most relevant findings of antisense approach application in glioma treatment pointing out the attention on effectiveness, delivery system possibilities, targeting modalities and safety of antisense strategy.

\section{Gliomagenesis}

Gliomagenesis is characterized by several biological events, such as activated growth factor receptor signaling pathways, downregulation of many apoptotic mechanisms and unbalance among proangiogenic and antiangiogenic factors (El-Aneed, 2004; Idbaih et al., 2008). Several growth factor receptors, such epidermal growth factor receptor (EGFR), platelet-derived growth factor receptor (PDRGF), C-Kit, vascular endhotelial growth factor receptor (VEGFR) and others growth factors receptors, are overexpressed, amplified and/or mutaded in gliomas. Features of the glioma cells are the loss of tumor suppressor genes, which are critical for the cell growth, differentiation and function. Table 1 summarizes the main genes involved in gliomagenesis.

\subsection{Genetic alterations in gliomas}

Gliomagenesis can develop through two different ways, resulting in evolution of a cluster genic alteration directly from normal astrocyte to GBM or by different kinds of mutations of various genes passing gradually from normal astrocyte to low-grade glioma, to high-grade glioma, to GBM. Primary GBM shows amplification of the epidermal growth factor receptor (EGFR), deletion or mutation of homozygous cyclin-dependent kinase (CDK) inhibitor p16 INK4A/(CDKN2A), alterations in tumor suppressor PTEN on chromosome 10, and deletion in the INK4a gene with loss of p14 and p16 (Hanahan \& Weinberg, 2000; Holland, 2001). Progression from low-grade to high-grade astrocytomas involve inactivating mutations of tumor-suppressor gene TP53 and elevated expression of platelet-derived growth factor (PDGF) ligands and receptors, accumulation of genetic alteration of 
retinoblastoma-associated cell-cycle regulatory pathways, including deletion or mutations of cyclin-dependent kinase inhibitor p16 INK4A/(CDKN2A) or the retinoblastoma susceptibility locus 1 (pRB1), as well as amplification or over-expression of cyclin-dependent kinase 4 (CDK4) and human double minute 2 (HDM2). Evolution to secondary GBM is associated with deletion of chromosome 10, which includes tumor-suppressor phosphatase and tensin homolog (PTEN). Additionally BcI2-like 12 increased expression (BcI2L12) inhibits apoptosis (Stegh et al., 2007). The astrocyte elevated gene-1 (AEG-1) is over-expressed in the majority of malignant gliomas and stimulates cellular transformation and invasion together with the Ha-ras family of retrovirus-associated DNA sequences (RAS) (Ohgaki and Kleihues 2007). Furthermore, oncogenic Ha-ras induces AEG-1 expression by modulating the phosphatidylinositol 3-kinase (PI3K)-Akt signaling pathway and contributes to the growth of HGGs. Mitogenetic signals activate a molecular cascade known as ras-mitogen activated protein kinase (Ras/MAPK). MAPK inhibits the Rb gene, activates the transcriptional factor E2F and cells enter the $S$ phase. The INK4a gene influences the Rb pathway by activating three cyclin kinase inhibitors: p15, p16, and p19.The final result is the blockage of cyclindependent kinase 2, 4 and 6, triggering cell-cycle progression by inhibiting $\mathrm{pRb}$.

\begin{tabular}{|l|l|l|l|}
\hline Genes & Chromosome & Molecular alterations & $\begin{array}{l}\text { Effects of molecular } \\
\text { alterations }\end{array}$ \\
\hline 3 & Cr17p13.1 & Mutation & $\begin{array}{l}\text { Cell cycle control loss, } \\
\text { proliferation }\end{array}$ \\
\hline $\begin{array}{l}\text { PDGF-A } \\
\text { PDGFR-a }\end{array}$ & Cr4q11-q12 & $\begin{array}{l}\text { Overexpression, } \\
\text { amplification }\end{array}$ & $\begin{array}{l}\text { Proliferation, } \\
\text { invasiveness }\end{array}$ \\
\hline $\begin{array}{l}\text { Unknown tumor } \\
\text { suppressor genes }\end{array}$ & $\begin{array}{l}1 \mathrm{p}, 19 \mathrm{q}, 4 \mathrm{q}, \\
\text { 9p,11p loss }\end{array}$ & Loss of heterozygosity & $\begin{array}{l}\text { Proliferation, } \\
\text { invasiveness }\end{array}$ \\
\hline $\begin{array}{l}\text { Unknown tumor } \\
\text { suppressor genes }\end{array}$ & Cr22q & Deletion & Proliferation \\
\hline Rb1 & Cr13q14.2 & Mutations/deletion & $\begin{array}{l}\text { Cell cycle control } \\
\text { loss, proliferation }\end{array}$ \\
\hline P16 & Cr9p & CDKN2/p16 deletion & $\begin{array}{l}\text { Cell cycle control } \\
\text { loss, proliferation }\end{array}$ \\
\hline PTEN & Cr10q23 & LOH & $\begin{array}{l}\text { Loss regulation } \\
\text { Akt/PKB pathway } \\
\text { proliferation, } \\
\text { tumor growth, } \\
\text { invasiveness, } \\
\text { angiogenesis }\end{array}$ \\
\hline DM2 & Cr12q14.3-q15 & Overexpression & $\begin{array}{l}\text { Pro-apoptotic action } \\
\text { loss, proliferation }\end{array}$ \\
\hline EGFR (c-erb-2) & Cr7p11-p12 & $\begin{array}{l}\text { Amplification, } \\
\text { overexpression }\end{array}$ & $\begin{array}{l}\text { Cell transformation, } \\
\text { proliferation }\end{array}$ \\
\hline
\end{tabular}

Table 1. Main genes involved in gliomagenesis 


\subsection{Angiogenesis}

Malignant gliomas are characterized by extensive microvascular proliferation and a higher degree of vasculature. The formation of new blood vessels from existing microvessels is angiogenesis, an histological indicator of the degree of malignancy and prognosis of patients. The presence of marked endothelial glomeruloid-like proliferations and of a positive immunoreaction at level of basament membrane (BM) in perivascular areas demonstrates active tumor invasiveness, disruption of pre-existing anatomical structures and neoplastic cellular migration along neoangiogenic vascular channel with evidence of proliferation of new fine capillaries (Caffo et al., 2004). Neovascularization in brain tumors correlates directly with their biological aggressiveness, degree of malignancy and clinical recurrence and inversely with the post-operative survival of patients affected by gliomas. Diffuse astrocytomas tend to progress from grade II to grade III tumors with a time interval of several years, whereas, progression of grade III to grade IV is more rapid, typically 2 years. Primary and secondary GBMs are morphologically indistinguishable and show their histologic hallmarks, i.e., "glomeruloid" microvascular tufts and necrosis. Glioma vasculature is structurally and functionally abnormal and it correlates and leads to vasogenic edema, increased interstitial pressure, and eterogeneous delivery of oxygen and drugs (Jain et al., 2007). The new vessel growth is stimulated by the secretion of proangiogenic growth factors; these factors bind to receptors on endothelial cells thereby activating them. The vascular endothelial growth factor (VEGF) acts as a major vascular permeability factor and as a mitogen/survival promoter for endothelial cells. The variant A of VEGF (VEGF-A) is secreted by tumor cells as well as by stromal and inflammatory cells. VEGF-A can be linked in the extracellular matrix through the interaction with proteoglycans or glycosaminoglycans. The expression of the receptors VEGFR1 and VEGFR2 is regulated on the endothelial cells in gliomas. The ligands for VEGF3 (VEGF-C\&D) are expressed by multiple cell types that surround the angiogenic vessels, suggesting the existence of a novel pro-angiogenic paracrine signaling pathways in these neoplasms. VEGF expression is stimulated by hypoxia and acidosis, and probably correlates with many other growth factors and their specific receptors (EGFR, HGFR, PDGFR, C-Kit, IGFR), and their downstream signaling pathways (PI3K-Akt, Ras-MAPK) upregulation and activation in gliomas. Basic fibroblast growth factor (bFGF) is expressed by vascular cells and, focally, by the tumor cells. The receptors for bFGF include FGFR1, expressed by both the tumor cells; FGFR2 expressed only by the tumor cells whereas FGFR4 is not detected in gliomas. The binding of VEGF on endothelial cells activates the phosphatidylinositol-3-hydroxyl kinase (PI3K)/protein kinase B (Akt) pathway, whereas the bFGF receptors are predominantly shown through the protein kinase $\mathrm{Ca}(\mathrm{PKCa})$ pathway. The activation of endothelial cells results in increased expression of cell adhesion receptors, such us integrins av $\beta 3$ and a5 $\beta 1$, and in increased cell survival, proliferation, and migration responses. Many other proangiogenic factors are upregulated in gliomas and this aspect might explain the failure of many actual antiangiogenic therapeutic strategies in gliomas management. An important role has absolved by bFGF, IL-1beta, IL-6, IL-8, TNF-alpha and stromal-cell-derived factor (SDF)-1 alpha (Idbaih et al., 2008). The angiopoietins are endothelial growth factors nad their signal transduction pathway passes via the Tie2 receptor tyrosine kinase expressed on endothelial cells. In particular, Ang-1 and -2, have been implicated in glioma angiogenesis (Holash et al., 1999). Ang-1 mediated activation of Tie2 is required for stabilization, 
remodelling and maturation of blood vessels, promotes angiogenesis and tumor growth and is associated with an increased number of highly branched vessels. VEGF and Ang-1 may act in concert (proliferation and maturation), while Ang-2 has been implicated in further remodeling of the initial microvasculature (Holash et al., 1999). Binding of Ang-2 to the Tie2 receptor on endothelial cells antagonizes this receptor's phosphorylation, thereby disrupting contacts between endothelial and periendothelial support cells and disengaging pericytes from the tumor vessels during initiation of vessel sprouting or regression. Examination of the expression patterns of angiopoietins and their receptors suggest a role in GBM vasculature and malignant transformation. Ang- 2 and Tie2 expression are absent in the normal brain vasculature but are induced in tumor endothelium of coopted tumor vessels prior to their regression. Treatment of glioma cell derived mouse xenografts with a dominant negative form of Tie2 results in a significant decrease in tumor growth (Zadeh et al., 2000). The discovery of hypoxia inducible factor-1 (HIF-1) and the observation that hypoxia-induced HIF-1a expression in pseudopalisading cells, into intratumoral necrotic areas, was concomitant with the expression of one of its target genes, VEGF, established a biological link between hypoxia and angiogenesis (Semenza, 2003). During embryonic development, blood vessels are newly formed from endothelial precursors and hematopoietic stem cells in a process known as vasculogenesis (Yancopoulos et al., 2000). In contrast, angiogenesis, the sprouting of new blood vessels from pre-existing ones results from an altered balance of proangiogenic factors and antiangiogenic factors. The sequence of events leading to the formation of new blood vessels is well characterized and involves an initial VEGF-mediated increase of vascular permeability leading to extravasation of plasma proteins associated with dilatation of native vessels and reduction in their pericyte coverage. Subsequently, endothelial cells migrate and proliferate. For the newly sprouting vessel is essential the deposition of proangiogenic matrix. This involves breakdown of the vascular basement membrane and extracellular matrix through the action of cathepsin B, matrix metalloproteases (MMPs) and other enzymes as well as the expression of matrix proteins such as fibronectin, laminin, tenascin-C and vitronectin (Gladson, 1999; Ljubimova et al., 2006). The angiogenic process culminates in the assembly of endothelial cells to form a vascular lumen followed by the elaboration of a new basement membrane and the recruitment of pericytes. In contrast to the accepted dogma that tumor development occurs in 2 phases (avascular and vascular), we observe that brain tumor growth follows two vascular phases. In the first vascular phase, the vessels are native cerebral vessels, which are coopted by tumor cells, while in the second phase, there is true neovascularization arising from existing vessels. During the transition period between these two phases, hypoxia driven HIF-1 expression occurs which results in VEGF secretion and the induction of neovascularization. In stage IV, angiogenesis adjacent to the necrotic area is triggered in response to increased expression of HIF-1a and VEGF, a process that rescues the remaining tumor cells. Thus, it is possible to suggest four sequential steps in glioma progression: $i$ ) perivascular organization, ii) proliferation, iii) vascular regression followed by necrosis, and iv) angiogenesis (Zagzag et al., 2000).

\subsection{Invasion}

Gliomas are almost invariably fatal and recur near the resection margin in almost all cases. It is unknown how invasive glioma cells survive in the setting of invasion, how they evade 
immune detection, how they thwart cytotoxic therapies and defer commitment to proliferation. Gliomas show a unique pattern of invasion and with rare exceptions, do not metastasize outside of the brain. The discrepancy between the tendency of gliomas to infiltrate along anatomically defined pathways with diffuse invasion of brain parenchyma and the rarity of metastases to extra-CNS domains remains enigmatic. It is probably possible to demonstrate the preference of the tumor cells to migrate along blood vessels and along myelinated fibre tracts of white matter, through the analysis of the pathways leading to the invasion of gliomas. Invading glioma cells normally migrate to distinct anatomical structures. These structures include the basement membrane of blood vessels, the subependymal space, the glial limitans externa and parallel and intersecting nerve fiber tracts in the white matter. Glioma cell invasion into perilesional tissue consists of an active translocation of glioma cells through host cellular and extracellular matrix barriers (Kohn \& Liotta, 1995). Three steps are fundamental in the phenomenon of glioma invasion: a) adhesion of glioma cells to proteins of the surrounding ECM mediated by cell adhesion receptors; b) proteases secretion by glioma cells which locally degrade the ECM components; c) migration of glioma cells into the newly created space through the ECM. ECM is composed of proteoglycans, glycoproteins, glycosaminoglycans and collagens, and also contains fibronectin, laminin, type I and IV collagen, tenascin, hyaluronic acid, vitronectin. It has turned out that the function of neurons and glia can be understood only in relation to their surrounding ECM and that the ECM via specific cell surface receptors play an important role in processes such as differentiation, apoptosis, and migration both in the normal and the pathologic nervous system. In recent years the glioma invasion has also been interpreted by numerous authors in terms of interaction between neoplastic cells and ECM. Critical factors include the synthesis and deposition of ECM components by glioma and mesenchymal cells, the release of ECM-degrading activities for remodeling interstitial spaces, the presence of adhesion molecules (matrix receptors on glioma cell surfaces that specifically recognize and adhere to ECM components) and the effects of cell-matrix interactions on the behavior of glioma cells. ECM modification aids the loss of contact inhibition allowing tumor cells to freely migrate and invade the surrounding tissues. Various ECM components, such us hyaluronan, vitronectin, tenascin-C, osteopontin are regulated within the tumor stroma and at the advancing edge of the tumor within brain parenchyma. Changes in these ECM components are felt to modulate brain tumor growth, proliferation and invasion, although specific interactions and exact mechanisms are unknown. This process is realized through specific receptors expressed on their surface. The integrins, a class of adhesion molecules and the hyaluronan receptor CD44 play a major role in glioma cell-matrix adhesion. Integrins regulate many aspects of the cell behavior including survival, proliferation, migration and differentiation. Integrins of the $\beta 1$ and av classes are expressed on different cell types, including neurons, glial cells, meningeal and endothelial cells. $\beta 2$ integrins are specifically expressed by leukocytes and they are found on microglia and on infiltrating leukocytes within the CNS, av $\beta 3$ integrins is associated with elevated levels of its ligands and with vitronectin in human gliomas. The decreasing, in vivo, of the $\beta 1$ subunit by an antisense strategy in the intracranial C6 glioma model leads to a integrin, this is highly expressed by tumor cells, at the invasive edge of the tumors and by endothelial cells associated with new blood vessels (Bello et al., 2001). Down-regulated $\beta 1$ integrin protein levels in vivo probably affect interactions of glioma cells with ECM components, leading to reduced migration along vascular basement membranes. These data can be interpreted as a contribute to the locally invasive behavior of astrocytic tumors, favoring the regulation of proteases activation. The proteolytic degradation of the basement 
membrane (BM) is mediated by proteases, such as the matrix metalloproteases (MMPs), secreted by tumor and stromal cells. MMPs are secreted as proenzymes and are activated by proteolytic cleavage of their amino-terminal domain. MMPs play an important role in human brain tumor invasion, probably due to an imbalance between the production of MMPs and tissue inhibitor of metalloproteases-1 (TIMP-1) by the tumor cells. Among these molecules, MMP-1 is the crucial enzyme able to initiate breakdown of the interstitial collagens, collagen type 1, collagen type 2 and collagen type 3 ; in this way it activates the other MMPs which allows the glioma cells to infiltrate normal brain tissue.

\section{The antisense strategy}

Over the last few years, attention has been focused on molecularly approaches. These include the development of monoclonal antibodies to specifically target cancer cells and small-molecule inhibitors of cell signalling pathways that have been linked to oncogenesis. Several approaches are available to specifically manipulate gene expression at the DNA or RNA stage of protein synthesis. In eukaryotic organisms, pre-mRNA is transcribed in the nucleus, introns are spliced out and then the mature mRNA is exported from the nucleus to cytoplasm. The small subunits of the ribosome usually starts by binding to one end of the mRNA and is joined there by other eukaryotic initiation factors, forming the initiation complex. This multi-enzymatic complex scans along the mRNA strand until it reaches a start codon, and then the large subunit of ribosome attaches to the small subunit and translation of a protein begins. This process, by which the information of a gene is converted into protein, is referred to as "gene expression". The antisense concept, regarding genic expression therapeutic modulation, is based on an understanding of nucleic acid structure and function and is dependent on Watson-Crick hybridization mechanisms. The goal of an antisense molecules-based approach is to selectively suppress the expression of a protein of interest by exploiting the genetic sequence in which it is encoded. The identification and validation of antisense inhibitors is the fastest way to identify inhibitors of gene expression. Moreover, as they are antisense inhibitors target RNA and not protein, they can be extremely specific and versatile in their action when properly used.

The antisense strategy was first proposed in 1970s. In this study the authors demonstrated the feasibility of using short antisense oligodeoxynucleotides to block the expression of targeted genes within intact cells. They already documented the use of a tridecamer oligonucleotide as a hybridization competitor to inhibit Rous sarcoma virus replication. This work provided the first evidence that oligonucleotides could be transported into cells ( Stephenson \& Zamecnik, 1978). The specificity of Watson-Crick hybridization is the basis for rational drug design of antisense oligonucleotides, leading to a new class of selective protein synthesis inhibitors The goal of an antisense molecules-based approach is to selectively suppress the expression of a protein by exploiting the genetic sequence in which it is encoded, acting at translational level (Jansen \& Zangemeister-Wittke, 2002; Tamm, 2006; Wacheck \& Zangemeister-Wittke, 2006).

Generally, systemic treatment with antisense oligonucleotides is well tolerated and sideeffects are dose-dependent. Dose-limiting toxicities include thrombocytopenia, hypotension, fever, and asthenia. Furthermore, an increase in concentration of the liver enzymes aspartate aminotransferase and alanine aminotransferase, as well as complement activation and a prolonged partial thromboplastin time, have been reported. AONs are relatively small, they have short DNA or RNA fragments, 13-25 nucleotides long, with a complementary 
nucleotidic sequence to sense DNA or mRNA (Baker et al., 2001; Wacheck \& ZangemeisterWittke, 2006). A DNA single strand or positive sense is normally called "sequence sense", when an RNA version of the same sequence exists and is then translated or translatable into protein. Antisense molecules interact with complementary strands of nucleic acids, modifying expression of genes. For a cell to use this information, one strand of the DNA serves as a template for the synthesis of a complementary strand of RNA. The template DNA strand is called the transcribed strand with antisense sequence and the mRNA transcript is said to be sense sequence (the complement of antisense). Because the DNA is double-stranded, the strand complementary to the antisense sequence is called nontranscribed strand and has the same sense sequence as the mRNA transcript. These antisense molecules may be introduced into a cell to silence one of many genic functions through inhibiting translation of a complementary mRNA by base pairing to it and physically obstructing the translation machinery. Antisense oligonucleotides inhibit mRNA function by several mechanisms, including modulation of splicing and inhibiting protein translation by disrupting ribosome assembly. However, the most important mechanism appears to be the utilization of endogenous RNase H enzymes (Dean \& Bennett, 2003; Wacheck \& Zangemeister-Wittke, 2006).

The use of triple-helix forming oligonucleotides or siRNA molecules are promising alternatives to antisense oligonucleotides. Although many oligonucleotides reportedly demonstrated activity against various viral targets, no oligonucleotide drug has yet been approved for routine therapeutic use, except fomivirsen (ISIS 2922), which is an antisense oligonucleotide composed of 21 phosphorothioate-linked nucleosides (PS-ON). It is administered intraocularly and is used for treatment of cytomegalovirus (CMV) retinitis in AIDS patients. However, it needs to be mentioned that this product has only relative importance and is only used in special cases, as CMV retinitis can be better treated with small molecules like HPMPC (recently approved by FDA and previously already available through an investigational newdrug (IND) program). Nevertheless, the approval of fomivirsen in 1998 was important to antisense technology as a whole, because it demonstrated that antisense drugs can be effective in the treatment of a local disease.

RNA- and DNA-based oligonucleotides are the most prevalent and most practical antisense drugs. There is difference between RNA-based and DNA-based antisense mechanism of action. Interactions of RNA-based antisense oligonucleotides with target mRNA inhibit gene expression by interfering with protein translation without nevessarily altering mRNA stability. Differently, double-stranded DNA/RNA in mammalian cells activates RNase Hmediated degradation of the target mRNA. RNase $\mathrm{H}$ recognizes the mRNA-(DNA) oligonucleotide duplex and cleaves the mRNA strand leaving the antisense oligonucleotides intact (Jason et al., 2004; Passioura \& Symonds, 2004). The arrest of translation by oligodeoxynucleotides which hybridize within the coding region or over the initiation codon is dependent on cleavage of the targeted mRNA by RNase $\mathrm{H}$. In some cases, but not all, binding of antisense sequences to the $5^{\prime}$ end of mRNAs was found to inhibit protein synthesis directly, presumably by interfering with the initiation of translation. Degradation of oligonucleotides in mammalian cells and in blood occurs most rapidly by exonucleases that can be blocked by end-group modifications.

Two alternative antisense-based approaches to modulate gene expression into cancer cells are RNA interference and ribozymes. RNA interference (RNAi) has emerged as an efficient and selective technique to provide stable inhibition of gene expression. This strategy, mediated by small double stranded RNA molecules, is normally an endogenous gene 
silencing mechanism physiologically used by eukariotes to regulate gene expression by reducing protein production and can also be exploited as a reverse genetic tool to study the function of genes associated with human diseases and as a therapeutic device to treat disease. Moreover RNA interference plays a fundamental role in diverse eukaryotic functions including viral defence, chromatin remodelling, genome rearrangement, developmental timing, brain morphogenesis, and stem cell maintenance. In mammalian cells RNAi can exist under two distinct forms of dsRNA, short interfering RNAs (siRNAs) and short hairpin RNAs (shRNAs). These last molecules then are processed into siRNAs by the multidomains enzyme DICER in an ATP dependent process. This enzyme is an endoribonuclease in the Rnase family that cleaves double-stranded RNA and pre-microRNA (miRNA) into short double-stranded RNA fragments called small interfering RNA about 2025 nucleotides long. DICER first processes input dsRNA into small fragments called short interfering RNAs, or microRNAs, which are the hallmark of RNAi. Dicer then helps load its small RNA products into large multiprotein complexes termed RNA induced silencing complexes (RISC). RISC and RISC-like complexes use the small RNAs as guides for the sequence-specific silencing of cognate genes through mRNA degradation, translational inhibition, and heterochromatin formation (Macrae et al., 2006). These siRNAs, through a second ATP-dependent molecular step, are then unwound and associate with the complementary RNA, through the action of a multiprotein complex known as the RNAiinduced silencing complex (RISC), and the target mRNA is cleaved within the region of complementarity to the siRNA. DsRNA and siRNA activate respectively two different molecular pathways. DsRNAs activate endogenous dsRNA-dependent protein kinase (PKR), leading to phosphorylation of the translation initiation factor EIF2a and finally to a general suppression of protein synthesis and to an upregulation of apoptosis. On the other hand, in mammalian cells, siRNAs lead to the knockdown of the target gene expression. The limit in clinic and therapeutic use of siRNA to modify strongly gene expression is represented from the transient effect of siRNA. These antisense molecules in fact, because of mammalian cells lack the RNA-dependent RNA polymerase, should be require the stable transfection into target cells by plasmid vectors. A peculiar distinctive characteristic between RNA interference and the other antisense approaches (antisense oligonucleotides and ribozymes) is the extreme selectivity for substrate from siRNA. In this way these antisense molecules may inhibit selectively the expression of oncogene containing a single point mutation, without suppress the expression of the wild-type transcript. RNA interference-based therapies are available to the targeting oncogenic transcripts in which two cellular genes have become fused, leading to the generation of an oncogenic fusion protein, such as Bcr-abl in myeloid chronic leukaemia (Jason et al., 2004; Passioura \& Symonds, 2004).

Ribozymes have been discovered in the early 1980s. These molecules are catalytic RNARNA enzymes. The first ribozyme discovered was found in the group I intervening sequence of the pre-mRNA of Tetrahymena thermophila (Cech et al., 1986) and was shown as a ribozyme with the capacity to catalyse its own excision (CIS acting ribozyme).

\section{Molecular targets}

In the last decade there have been various studies that have demonstrated efficacy of antisense therapy in vitro and in vivo in oncological diseases and, specifically, in brain tumor. Different target molecules at different steps and pathways, such as cell 
immortalization and apoptosis escape, tumor neoangiogenesis, invasion of normal tissues have been studied and chosen as a possible target of new antisense therapeutic model in glioma treatment. In table 2 are reported the mainly molecular targets.

\begin{tabular}{|c|c|c|c|}
\hline Molecular target & Normal function & \begin{tabular}{|l|}
$\begin{array}{l}\text { Kind of } \\
\text { mutation }\end{array}$ \\
\end{tabular} & Effect of mutation \\
\hline Bcl-2 & $\begin{array}{l}\text { Prevents the release of } \\
\text { cytochrome } C \text { from the } \\
\text { mitochondria. }\end{array}$ & Overexpression & $\begin{array}{l}\text { Inhibition of apoptosis } \\
\text { and increase of resistance } \\
\text { to chemo- and } \\
\text { radiotherapies. }\end{array}$ \\
\hline PKC- $\alpha$ & $\begin{array}{l}\text { Involved in growth- } \\
\text { factor-mediated signal } \\
\text { transduction pathways. }\end{array}$ & Overexpression & $\begin{array}{l}\text { Upregulation of cancer } \\
\text { cell, proliferation and } \\
\text { tumor growth. }\end{array}$ \\
\hline $\begin{array}{l}\text { TGF- } \beta 2 \\
\text { (Glioblastoma- } \\
\text { derived T-cell } \\
\text { suppressor factor, } \\
\text { G-TSF, BSC-1 cell } \\
\text { growth inhibitor) }\end{array}$ & $\begin{array}{l}\text { It suppresses the effects } \\
\text { of interleukin dependent } \\
\text { T-cell tumors. }\end{array}$ & Overexpression & $\begin{array}{l}\text { Downregulation of } \\
\text { apoptosis and tumor } \\
\text { growth. Increases ECM } \\
\text { invasion and induces } \\
\text { escape of tumor from } \\
\text { immunosurveillance. }\end{array}$ \\
\hline Telomerase (h-TR) & $\begin{array}{l}\text { Reverse transcriptase } \\
\text { that carries its own RNA } \\
\text { molecule, which is used } \\
\text { as a template when it } \\
\text { elongates telomeres. }\end{array}$ & Overexpression & $\begin{array}{l}\text { Cancer cell } \\
\text { immortalization, tumor } \\
\text { growth. }\end{array}$ \\
\hline $\begin{array}{l}\text { Focal adhesion } \\
\text { kinase (FAK) and } \\
\text { insulin-like growth } \\
\text { factor I receptor } \\
\text { (IGF-IR) }\end{array}$ & $\begin{array}{l}\text { FAK is a protein tyrosine } \\
\text { kinase which is recruited } \\
\text { at an early stage to focal } \\
\text { adhesions, leading the } \\
\text { cytoskeleton to interact } \\
\text { with proteins of the } \\
\text { ECM, and initiate events } \\
\text { as cell migration and } \\
\text { anchorage-dependent } \\
\text { differentiation. } \\
\text { Transmembrane receptor } \\
\text { that is activated by IGF-1 } \\
\text { and by the related } \\
\text { growth factor IGF-2. It } \\
\text { belongs to the large class } \\
\text { of tyrosine kinase } \\
\text { receptors. This receptor } \\
\text { mediates the effects of } \\
\text { IGF-1. }\end{array}$ & $\begin{array}{l}\text { Overexpression } \\
\text { Gene } \\
\text { amplification }\end{array}$ & $\begin{array}{l}\text { Cancer cell proliferation, } \\
\text { downregulation of } \\
\text { apoptosis and tumor } \\
\text { growth. }\end{array}$ \\
\hline $\begin{array}{l}\text { PTEN } \\
\text { (MMAC 1) }\end{array}$ & $\begin{array}{l}\text { Tumor-suppressor gene } \\
\text { located on human } \\
\text { chromosome 10q23.3, }\end{array}$ & $\begin{array}{l}\text { Nonsense } \\
\text { mutation, LOH }\end{array}$ & $\begin{array}{l}\text { Cancer cell proliferation, } \\
\text { downregulation of } \\
\text { apoptosis, tumor growth, }\end{array}$ \\
\hline
\end{tabular}




\begin{tabular}{|c|c|c|c|}
\hline Molecular target & Normal function & $\begin{array}{l}\text { Kind of } \\
\text { mutation }\end{array}$ & Effect of mutation \\
\hline & $\begin{array}{l}\text { regulating cell growth, } \\
\text { apoptosis, interaction } \\
\text { with ECM and inhibiting } \\
\text { cell migration, as well as } \\
\text { spreading and focal } \\
\text { adhesion. }\end{array}$ & & invasion. \\
\hline $\begin{array}{l}\text { PI3K/AKT/PKB } \\
\text { (pathway of bFGF, } \\
\text { PDGF, IGF, VEGF, } \\
\text { EGFR) }\end{array}$ & $\begin{array}{l}\text { Pathway involved in cell } \\
\text { survival. AKT has an } \\
\text { antiapoptotic effect by } \\
\text { inactivating the } \\
\text { proapoptotic BAD, } \\
\text { procaspase-9 and fork- } \\
\text { head transcription factors } \\
\text { (activation of Fas ligand). } \\
\text { AKT induces NF-kB- } \\
\text { dependent pro-survival } \\
\text { genes expression (BCL- } \\
\text { xL, C-Myb), modifies cell } \\
\text { cycle progression by } \\
\text { inhibiting p27 and p21, } \\
\text { up-regulates } \\
\text { transcription of cyclin D } \\
\text { and promotes nuclear } \\
\text { entry of mdm2. }\end{array}$ & $\begin{array}{l}\text { Overexpression } \\
\text { Gene } \\
\text { amplification }\end{array}$ & $\begin{array}{l}\text { Upregulation of cancer } \\
\text { cell proliferation, loss of } \\
\text { cell cycle control, } \\
\text { increased telomerase } \\
\text { activity, cell invasiveness } \\
\text { and angiogenesis by } \\
\text { stimulating secretion of } \\
\text { MMPs and by activating } \\
\text { endothelial nitric oxide } \\
\text { synthase (eNOS). }\end{array}$ \\
\hline
\end{tabular}

Table 2. Principal molecular pathways involved in gliomagenesis and glioma angiogenesis.

\subsection{BCL-2}

Apoptosis is an important process involved in cell survival. In particular exist two different constitutive apoptotic pathways, the extrinsic pathway, that starting from external death signals induces the activation of the caspase pathway through initial activation of caspase- 8 , and the intrinsic one. This last pathway involves Bcl-2 family proteins. Inside the extrinsic apoptotic pathway, Zhou et al have demonstrated the upregulation of glioma cells apoptosis through activation of caspase 9 and 3 (Zhou et al., 2010).

$\mathrm{Bcl}-2$ gene is one of the most important proto-oncogenes, proptpypical inhibitor of apoptosis, located at the breakpoints of $\mathrm{t}(14 ; 18)$ chromosomal translocations in low-grade Bcell non-Hodgkin's lymphomas. BCL-2 encodes an oncogenic mitochondrial protein with transport functions and its expression level is very increased in many types of cancer, such as follicular non Hodgkin lymphoma, other lymphomas, leukemias and lung, breast, colorectal, gastric, prostate, renal cancer and neuroblastoma. BCL-2 protein prevents the release of cytochrome C from the mitochondria (GROSS 99), inhibiting in this way apoptosis. Normally, in response to DNA damage, to cellular stress and to other cellular damage signals, BCL-2 induces the release of cytochrome c from mitochondrial matrix to cytosol, where it activates caspase-9 and caspase-3 through the activation of Apaf-1 (El- 
Aneed, 2004). This overexpression of BCL-2 make it a very promising target for the antisense therapy, in consideration also of the BCL-2 protein effect on chemo/radiation resistance. In fact, the BCL-2 group of proteins has been implicated not only in the pathogenesis of cancer but also in resistance to cancer treatment. Thus, the antisense modulation of BCL-2 (mRNA or protein) expression could increase the effectiveness of conventional chemotherapeutic agents. A phase II trial is underway with G3139 in combination with standard chemotherapy for patients with relapsed, chemotherapy resistant non-Hodgkin's lymphoma. Overexpression of BCL-2 is not uncommon in non-B cell malignant tumours. Human melanoma expresses BCL-2 in up to $90 \%$ of all cases. Jansen and colleagues showed that G3139 improves the chemosensitivity of human melanoma transplants in severe combined immunodeficient mice. Additionally, in a phase I/II study, Jansen's group tested the combination of G3139 and dacarbazine in patients with advanced malignant melanoma. In a within-patient dose-scalation protocol, G3139 0.6-6.5 mg/ $\mathrm{kg}$ was given intravenously or subcutanously to 14 patients with advanced malignant melanoma along with standard dacarbazine treatment. In serial tumour biopsy samples, BCL2 concentrations were measured by immunoblot, and apoptosis of tumour cells was assayed. The combination regimen was well tolerated with no doselimiting toxicity. Haematological abnormalities were mild to moderate. Lymphopenia was common. High doses of G3139 were associated with transient fever. Four patients had liver-function abnormalities that resolved within 1 week. Steady-state plasma concentrations of G3139 were obtained within $24 \mathrm{~h}$ and increased with the administered dose as assessed by liquid chromatography. By day 5, daily doses of $1.7 \mathrm{mg} / \mathrm{kg}$ and higher led to a median decrease of BCL2 expression of $40 \%$ in melanoma samples compared with baseline. Reduced BCL2 expression was associated with increased apoptosis of tumour cells. Apoptosis was further enhanced after dacarbazine treatment. Six of 14 patients showed antitumour responses. The estimated median survival of all patients was more than 12 months, which compares favourably with survival of stage IV malignant melanoma patients (usually 6-9 months with and without treatment). This study is worth mentioning because it was the first antisense trial in which downregulation of the target protein in the target tissue was shown (Jansen \& Zangemeister-Wittke, 2002). Based on the promising results of this study, the combination of dacarbazine and G3139 therapy in patients with malignant melanoma received fast-track approval by the FDA, and is in a phase III multicentre trial (Pirollo et al., 2003). Phase I and II studies are also being done to test G3139 in combination with docetaxel in patients with advanced breast cancer, hormone-refractory prostate cancer, and other solid tumours. Another phase I study is analysing the combination of G3139 and mitoxantrone in patients with hormone refractory prostate cancer. In 21 individuals treated so far, toxicities were transient and included neutropenia (grade 3), lymphopenia (grade 2), fatigue, arthralgias, and myalgias (all grade 1). No dose limiting toxicities were reported for the doses tested, and one patient had a greater than $50 \%$ response to prostate specific antigen with symptomatic improvement in bone pain. Another phase I study has been started to test G3139 together with salvage chemotherapy of fludarabine and cytarabine in patients with refractory or relapsed acute myelogenous leukaemia or acute lymphocytic leukaemia. Furthermore, a phase I/II trial of a combination treatment of G3139 and irinotecan has been initiated in patients with metastatic or recurrent colorectal cancer. So far, no results are available for these two trials. By using antisense oligonucleotides against the first six codons 
of the human bcl-2 gene transfected into malignant glioma cells (Jon52 and Roc glioblastoma cell lines), Julien et al. demonstrated a decrease in cell growth and an increase in apoptotic death (Julien et al., 2000). As to BCL2 proteins family role in apoptotic cell death regulation, Guensberg et al. showed that resistance to chemotherapy in glioblastoma is linked to the expression of antiapoptotic Bcl-2 family members, including Bcl-xL. The authors used antiBcl-xL antisense oligonucleotides (ISIS 16009, ISIS 16967) in M059K glioblastoma cell lines and demonstrated a strong correlation between reduction of Bcl-xL protein expression, induction of intrinsic apoptotic pathway and enhancement of cytotoxic responses to paclitaxel treatment, resulting in a chemosensitizing effect of anti-Bcl-xL therapy (Guensberg et al., 2002).

\subsection{Protein Kinase C- $\alpha$ (PKC- $\alpha)$}

A key regulatorin the glioma cell differentiation and proliferation is protein kinase C-alpha (PKC-alpha). This protein, translated from the mRNA of pkc-a gene, located on chromosome 16p11.2-q12.1, is a member of family of cytoplasmic serine-threonine protein kinases, strongly involved in growth-factor-mediated signal transduction pathways, in order to reach a key role in regulating cell differentiation and proliferation. Its involvement in oncogenesis is suggested by the fact that they are the major intracellular receptors for tumour-inducing phorbol esters. Among the various PKC isoenzymes, PKC- $\alpha$ may show the greatest degree of overexpression in transformed cell lines as compared to normal astrocytes in brain tissue peritumoral samples. The overexpression of this transduction signal protein has been implicated in various kinds of tumors, such as breast, colon, lung, ovarian cancer, melanoma, brain tumors (Campbell \& Pollack, 1997; Pirollo et al., 2003). PKC-a inhibitors such as tamoxifen and UCN-01 rich a very high amount of down-regulation of in vitro growth and in vivo tumorigenicity. Moreover, numerous in vitro and in vivo animal studies have showed the efficacy of antisense oligonucleotides against PKC- $a$ in the cancer growth inhibition. ISIS 3521 is the most experimented in order to test the in vitro and in vivo effects of the PKC-a downregulation towards cell proliferation and tumors, such as NHL, ovarian cancer, NSCLCs, kidney clear cell carcinoma. Results of a phase I study suggested that an antisense oligonucleotide directed against PKC-alpha (ISIS 3521) might be effective in the treatment of low-grade lymphoma. In this trial ISIS 3521 was delivered over 21 days by continuous intravenous infusion followed by a 7-day rest period. In an in vitro study of A549 lung epithelia cells, McKay et al. have shown depletion of PKC-a expression by antisense oligonucleotides leading to a reduction in c-jun expression but c-fos or junB (McKay et al., 1999). This is a crucial pathway in cell growth, cell death and its proliferation. The transcription factor c-Jun is one of major targets of JNK phosphorylation. JNK activation and c-Jun phosphorylation are involved in the induction of apoptosis (Potapova et al., 2000). Inhibition of PKC- $\alpha$ expression, at mRNA level, by a syntetic antisense oligonucleotide has been shown to inhibit proliferation of C6 glioma cells and in vitro and in vivo growth inhibition of transformed U-87 cells transfected with a PRSV vector loading antisense anti-PKC- $\alpha$ oligonucleotide, and, respectively, in vivo subcutaneous tumorigenicity lost (Pollack et al., 1996). Grossman et al. studied the therapeutic efficacy and toxicity of a phosphorothioate antisense oligonucleotide (Aprinocarsen, Eli Lilly LY9000003) directed against PKC- $\alpha$ in patients with recurrent malignant gliomas. In this clinical phase II study no clinical benefit was seen, probably because of tumor growth or the effect of Aprinocarsen on BBB, whose mechanisms are unknown (Grossman et al., 2004). 
Other potential therapeutic targets of antisense therapy are human C-raf kinase and c-KiRAS proteins and signal transduction kinase proteins, involved in the control of proliferation, cellular migration, differentiation and cytoskeletal rearrangements. Monia et al. demonstrated the evidence of antitumor activity of phosphorothioate antisense inhibitor C-raf Kinase (ISIS 5132 or CGP69846A) in tumor-bearing mice, demonstrating an important reduction of tumor growth (Monia et al., 1996). Chen et al study has documented a valid role of oncogenic Ha-RAS oligo (ISIS 2503) in the proliferation of T24 cells in human bladder carcinoma (Chen et al., 1996).

\subsection{TGF- $\beta 2$}

A key role in gliomagenesis is absolved by TGF- $\beta 2$ and consequently this growth factor represent an important target of antisense therapy. TGF- $\beta 2$ role in brain tumor and in glioma progression in particular was investigated in 1993 by Jachimczak et al. The authors demonstrated the efficacy of specific antisense therapy in down-regulation of TGF- $\beta 2$, through stimulation of antitumoral immunosurveillance. In HTZ-153, HTZ-209 and HTZ243 glioblastoma and malignant astrocytomas cell lines, TGF- $\beta 2$ specific phosphorotioate antisense oligonucleotides enhanced lymphocyte proliferation up to 2.5 fold and autologous tumor cytotoxicity up to $60 \%$. Through an antisense therapy against TGF- $\beta 1$ and- $\beta 2$ in 12 glioma cell lines, another study of the same research group has showed that the effect of anti-TGF- $\beta 2$ phosphorotioate antisense oligonucleotides is much stronger than anti-TGF- $\beta 1$ ones (Hau et al., 2009; Jachimczak et al., 1996). This cytokine binds to TGF- $\beta$ receptors (TBR) and initiates a signaling cascade via cytoplasmic signaling mediators (Smads) into the nucleus, inducing regulation of target gene expression. Besides this pathways, other intracellular TGF- $\beta$ activated pathways include mitogen- activated protein kinase (MAPK), N-RAS, Ral guanine nucleotide exchange factors (Ral-GEF), PI3-K/Akt), c-Jun-NH(2)terminal kinase (JNK), p38-P and protein phosphatase 2A (PP2A/p70s6K). During tumorigenesis, TGF- $\beta$ increases extracellular matrix invasion and induces escape of tumor from immunosurveillance. In this study antisense compound AP 12009 (antisense oligonucleotide anti TGF- $\beta 2$ mRNA) enhanced the immune cell mediated cytotoxic antitumor response against tumor cells (Hau et al., 2007; Schlingensiepen, 2005, 2006). Schneider et al. have examined a "double-punched" approach to overcome the escape of glioblastoma cells to the immune surveillance, through an active specific immunization (ASI) with Newcastle-Disease-Virus infected tumor cells and blocked the TGF- $\beta$ production by delivery of TGF- $\beta$ antisense oligonucleotides using polybutyl cyanoacrylate NPs. This approach induced a significant decrease in plasma TGF- $\beta 2$ level as well as an increase in rate of high affinity IL-2 receptor (CD25) on lymphocytes and consequently of antitumoral cytotoxicity (Schneider et al., 2008).

\subsection{Human telomerase}

Kondo et al. demonstrated in vitro and in vivo that anti-hTR antisense treatment suppressed tumor cell growth and survival by inducing apoptosis, by treating malignant glioma cells (U251-MG cells) in culture with 2-5A antisense oligonucleotide against telomerase RNA and by inoculating this antisense molecule directly into tumors induced in nude mice (Kondo et al., 1998). This study group showed in vitro that human telomerase antisense inhibition induced two different pathways: apoptosis and differentiation in subpopulations of malignant glioma cells that escape from apoptotic crisis. Probably, malignant glioma cells are cells in G2/M phase in contrast with the major percentage of apoptotic cells that are in $\mathrm{S}$ 
phase of the cell cycle. These results indicate that antisense hTR reduced cell cycling and caused an accumulation of cells in G2/M. Treatment of surviving nonapoptotic cells with antisense oligonucleotides against p27, but not against p21, (two important cyclindependent kinase inhibitors-CDKIs) induced apoptotic cell death; this suggests that p27 may have a protective role for the survival of differentiating glioma cells (Kondo et al., 1998). The efficacy in vitro and in vivo murine model combined with therapy with 2-5A anti-hTR and recombinant adenovirus p53 (Ad5CMV-p53) was showed by Komata et al. in malignant glioma cell lines with mutant p53 and in vivo GBM murine model (Komata et al., 2000). By using an antisense oligonucleotide against hTER (the RNA component of telomerase), Mukai et al. detected many telomerase-positive tumor cells in the vast majority of malignant gliomas (Mukai et al., 2000). In a recent in vitro study (U87-MG and U373-MG human malignant glioma cells cultures, cell cultures of human astrocytes expressing telomerase with or without oncogenic Ras) and in vivo (murine model) study, it was demonstrated that treatment with 2-5A-anti-hTR in the presence of N, N'-bis (2chloroethyl)-N.nitrosourea (BCNU), cisplatin (CDDP) and temozolomide (TMZ) better enhanced the cell-killing effect if done sequentially rather than concurrently; treatment with 2-5A-anti-hTR in the presence of paclitaxel (PTX) and $\gamma$ irradiation (IR) always enhanced this effect. The enhanced cell-killing resulted by up-regulation of apoptosis. 2-5A-anti-hTR did not impair the autophagy induced by treatment with TMZ or IR and a synergistic combined effect. In animal xenograft study model, TMZ enhanced the anti-tumor effect of 25A anti-hTR via induction of apoptosis (Iwado et al., 2007).

In an in vivo murine model, created by implantation of U-87 MG malignant glioma cells in mouse, Im et al. demonstrated the suppression of the ability of glioma cells to form tumors in mice. This result was obtained after transfection of antisense VEGF cDNA in an antisense orientation through the recombinant adenoviral vector Ad5CMV-aVEGF. Infection of U-87 MG malignant glioma cells resulted in the reduction of the level of the endogenous VEGF mRNA and drastically decreased the production of the targeted secretory form of the VEGF protein (Im et al., 1999).

Resnicoff et al. examined the role of IGF-1R in the growth of rat GBM cells and focused the attention on IGF-1R pathway, which is critical in the regulation of cell proliferation. In fact, neuroglial cell growth and CNS development are normally strongly regulated by IGF-1 and IGF-2 via IGF-1R. By introducing a plasmid expressing an antisense RNA to IGF-1R RNA, the study demonstrated the reduction of IGF-1R levels in cell growth in vitro, anchorageindependent growth and prevention of the development of tumors in rats (Resnicoff et al., 1994). Andrews et al. observed that IGF-1R AONs-treated autologous glioma cells, collected during surgical treatment, were induced toward apoptosis and that, in an in vivo murine model, they gave rise to a host response (Andrews et al., 2001).

Liu et al. showed the crucial involvement of two signal transduction pathways, respectively activated by focal adhesion kinase (FAK) and insulin-like growth factor I receptor (IGF-IR) kinase into gliomagenesis. In this in vitro and in vivo study (U87 and LN229 glioma cell lines and mice bearing intracranial glioma xenografts) the authors demonstrated that TAE226, a potent ATP-competitive inhibitor of several tyrosine kinases (such as FAK and IGF-IR kinase) down-regulated proliferation and invasion of glioma cells and inhibited cell cycle progression particularly at the G2-M checkpoint. TAE226 also gave rise to a concomitant reduction of the expression of p-cdc2 (Tyr15) and cyclin B1, increase in apoptosis and reduction in glioma invasion in an in vitro Matrigel (Liu et al., 2007). The central role of FAK has already been examined in $\mathrm{Wu}$ et al. study. By using anti-FAK 
phosphotothioate antisense oligonucleotides packaging into liposomes in U251 MG cells, the authors showed down-regulation of expression levels of FAK and activation of apoptosis, through increase in caspase-3 activity, which is a key-mediator of apoptosis in mammalian cells. In fact, FAK activates the PI3K survival pathway with the concomitant activation of nuclear factor Kappa B (NF-kB) and induction of inhibitor of apoptosis (Wu et al., 2006).

Another possible interesting target of antisense therapy could be PTEN or MMAC 1, a tumor-suppressor gene located on human chromosome 10q23.3, regulating cell growth, apoptosis, interaction with extracellular matrix and inhibiting cell migration, as well as spreading and focal adhesion. PTEN protein has two different phosphatase activities: a lipid-phosphatase activity and a protein-phosphatase activity. Substrates of these specific phosphatase activities are phosphatidylinositol 3,4,5-triphosphate and phosphatidylinositol 3,4-biphosphate; they are both involved in the PI3K FAK pathways. In Park et al. study, it was demonstrated that PTEN has an important role in the inhibition of hyaluronic acidinduced MMP-9 secretion, in the down-regulation of basal levels of MMP-2 and in the increase in expression levels of the tissue inhibitor of metalloproteinase- 1 and -2 (Park et al., 2002).

\subsection{PI3K/AKT/PKB pathway}

Among the different growth factors/receptors pathways involved in tumorigenesis of brain tumors, such as bFGF, PDGF, IGF, VEGF, EGFR, a crucial role plays PI3K/AKT/protein kinase $\mathrm{B}(\mathrm{PKB})$ pathway, normally involved in cell survival. AKT is a subfamily of the serine/threonine kinases that includes AKT1, AKT2 and AKT3. Growth factors and their receptors led to the activation of PI3K, which in turn phosphorilates phosphotidylinositol3,4-biphosphate (PIP2) to phosphotidylinositol-3,4,5-triphosphate (PIP3). PIP3 binds to PH domain of AKT and gives rise to AKT activation. AKT has an antiapoptotic effect by phosphorilating and inactivating the proapoptotic BAD, procaspase-9 and fork-head transcription factors. These molecules activate Fas ligand; moreover AKT also induces NF$\mathrm{kB}$-dependent transcription of pro-survival genes including BCL-xL, C-Myb, modifies cell cycle progression by inhibiting p27 and p21, up-regulates transcription of cyclin D and promotes nuclear entry of $\mathrm{mdm} 2$. It also leads to degradation of p53 and to uncontrolled cell proliferation. AKT enhances telomerase activity and promotes cell invasiveness and angiogenesis by stimulating secretion of MMPs and by activating endothelial nitric oxide synthase (eNOS). In an in vitro and in vivo murine model, Pu et al. showed the downregulation of proliferation rate of $\mathrm{C} 6$ glioma cells transfected with antisense AKT2 cDNA construct. Parental C6 cells and C6 cells, transfected with antisense construct, were stereotactically implanted into the right caudate nucleus of rats through lipofectamine complexes. Antisense inhibition of AKT2 resulted in the reduction of growth rate and proliferation of C6 cells, as well as in the up-regulation of GFAP expression and in the induction of apoptosis (Pu et al., 2006). Inside this crucial molecular pathway, an important potential molecular target of gliomas antisense therapy is HER1/EGFR signal transduction pathway. This tyrosine kinase receptor can show various kinds of alterations such as gene amplification or overproduction of HER1/EGFR ligands. There are various mutant forms of HER1/EGFR. The most important mutated hysoform is EGFRvIII, characterized by a truncated extracellular domain, is the most studied mutant form; it lacks of a ligand-binding domain and is constitutively activated. This mutant form has been detected in several human cancers including NSCLC, breast carcinomas, ovarian carcinomas and gliomas. 
Studies in human GBM cells, in human xenografts models and in GBM patients suggest that EGFRvIII promotes tumor growth and progression via constitutive activation of the PI3K/Akt pathway; it also induces up-regulation of cell proliferation via the MAPK/ERK1/2 signal transduction pathway. New therapeutic strategies through small-molecule HER1/EGFR TK inhibitors (erlotinib and gefitinib) and monoclonal antibodies (cetuximab) may be future therapeutic perspectives in gliomas therapy. The use of antisense RNA into murine models of human glioma, through liposomes tagged with monoclonal antibodies, facilitates tumor targeting and induces reduction of HER1/EGFR expression increasing survival (Halatsch et al., 2006).

\subsection{C-Met/HGF}

C-Met is a tyrosine kinase receptor whose ligand is hepatocyte growth factor (HGF). This pathway is very critical in cellular proliferation, motility and invasion and it is overexpressed in gliomas. Chu et al. demonstrated in vitro and in vivo that AONs against c-Met (FAM-labeled c-Met nonsense ODNs-LIPOFECTAMINE PLUSTM GIBCO Laboratories, Grand Island, NY) markedly suppressed the expression of c-Met mRNA in human glioma cells and cell growth. Inhibition of c-Met gene expression by antisense AONs enhanced significantly the cytotoxic effect of radiation on human U251 glioma cells in culture (Chu et al., 2006). In a successive research, the same study group showed that c-Met antisense oligonucleotides, injected intratumoral in the rat, were well tolerated at therapeutic levels and did not produce any toxic effects and recently have increased sensitivity of human glioma cells to paclitaxel, leading to a potential targeted-enhanced chemotherapeutic approach tightly selective against glioma cells (Chu et al., 2010).

\subsection{ECM proteins}

Khazenzon et al. have demonstrated the effects of antisense inhibition of laminin- 8 expression in glioma therapy through an in vitro model using human glioblastoma multiforme cell lines M059K and U-87MG co-cultured with normal human brain microvascular endothelial cells (HBMVEC). Endothelial cells contribute laminins containing a4 and a5 chains, whereas glial cells synthesize laminins containing a1 and a2 chains. In human brain capillaries, laminin-8 is the most expressed laminin. During progression of human gliomas, the expression of capillary BM laminins containing a4 chain switches from the predominant laminin-9 into lanimin- 8 . Laminin- 8 and its receptor, integrins a $3 \beta 1$ and a6 $\beta 1$, are important for the functioning of endothelial cell BMs, which play a role in the maintenance of the BBB. Laminin- 8 ( $\alpha 4$ and $\beta 1$ chains) plays an important role in glioma cell invasiveness, in combination with other proteins associated with glioma progression, such as tenascin-C, MMP-2 and MMP-9. In fact, up-regulation of laminin-8 expression in both glioma cells and glioma-adjacent capillary endothelial cells may reduce glial cell adhesion and enhance migration, which is necessary for local tumor invasiveness. The result of this study was a significant reduction of invasion of co-cultures through Matrigel and through the use of morpholino oligos against $\alpha 4$ and $\beta 1$ chains of laminin-8 (Khazenzon et al., 2003).

\subsection{UPAR}

Among the possible key molecules of gliomagenesis, the urokinase-type plasminogen activator receptor (uPAR) may be particularly important in regulating plasminogenmediated extracellular matrix proteolysis on the cell surface. Through an antisense anti- 
UPAR therapy, Mohanam et al. showed in vitro a markedly lower level of ECM degradation with down-regulation of MMP-2 activity and consequently a down-regulation of surrounding tissue invasion pathways (Mohanam et al., 1997).

\section{Conclusions}

The treatment of gliomas represents one of the most challenging areas in neurosurgery and oncology. Malignant gliomas involves multiple aberrant signaling pathways and the blood brain barrier (BBB) restricts the delivery of many chemotherapeutic agents. The efficectiveness of the actual chemotherapeutic approach, multimodal targeted therapies, differently than the other malignant extracerebral tumors, remains very modest in gliomas. Considering the multitude of molecular entities and signaling pathways regulating the proliferation and cellular survival/cell death, the inhibition of a singular target gene or transcriptional factor could not be sufficient to suppress neoplastic progression. In this intricate and complex field it seems to be very important to improve specific selective drugs delivery systems to lead to diffusion of drugs, antisense oligonucleotides, small interference RNAs, engineered monoclonal antibodies and other therapeutic molecules into CNS overcoming BBB.

Antisense therapy is an interesting field of base and translational research in cancer therapy. This approach has been applied in various kinds of tumors and showed a very high specificity and efficacy against cancer cells. Many antisense oligonucleotides have shown sharp in vitro reduction in target gene expression and promising activity against a variety of human malignancies. Several experimental in vitro and in vivo studies in cell lines cultures and animal models showed inhibition of genes involved in cell proliferation, apoptosis and angiogenesis. Clinical trials demonstrated a good tolerability and no increment of toxicity of antisense oligonucleotides (Caruso et al., 2010a).

However, considering the multitude of molecular entities and signalling pathways that regulate the proliferation and cellular survival/cell death, inhibition of a singular target gene or transcriptional factor could not be sufficient to suppress neoplastic progression. Glioma cell invasion is a complex and multifactorial mechanism involving a large series of molecules and cell-cell and cell-ECM interactions. These processes allow individual tumor cells to migrate and invade the surrounding brain parenchyma. ECM, proteases, cell adhesion molecules and their related signalling pathways show an important role in glioma cell migration and invasion. It is evident that the complexity and cross-talk between signal transduction pathways limits the potential efficacy of targeting a single receptor or molecule. Future possible interesting molecular target in antisense glioma therapy, tested in preclinical study, may be clusterin, eIF-4E (eukaryotic initiation factor-4E), integrins, metalloproteinases and other key molecules involved in invasion and angiogenesis.

We now are investigating about the role of HIF (Hypoxic inducing factor) isoforms and IL-8 (Interleukine-8) in glioma progression. HIF-1a appears to be a highly involved factor in the development of a characteristic tumor phenotype influencing growth rate, invasiveness and metastasis. In fact it has to be taken into account that HIF-1a does not only regulate actively downstream processes but is also itself influenced by the tumor microenviroment in many different ways. As a result, local ipoxia, due to increased proliferation or insufficient oxygen supply, inactivation of tumor suppressors, oncogenes and growth factors, along with other cell types, such as macrophages, contribute to form a tumor microenviroment capable to 
modulate the HIF response itself. A highly specific targeting of the organ or tissue is mandatory: HIF-1 inhibitors for cancer therapy target the HIF pathway on different levels: they decrease HIF mRNA or proteins levels, inhibit DNA binding or decrease HIF-mediated transactivation. Antisense inhibition of HIF may be a strong target for anti-angiogenic therapy. In fact, HIF is the crucial molecule and transcriptional factor produced in response to hypoxic conditions within HIF-1a/VEGF-regulation expression-dependent angiogenic pathway. In this molecular cascade HIF-1a up-regulated levels finally induce up-regulation of VEGF expression, and, at the same time, may stimulate gene expression of other genes involved in gliomagenesis. Our study group has recently showed high expression levels of PGES-1 (Prostaglandine E 1 Sinthase) and IL-8 in high grade glioma cells and microglial cells, strongly correlated with grading tumor (Caruso et al., 2010a).

During malignancy progression gliomagenesis, leukocyte infiltration and necrosis are two biological phenomena associated with the development of neovascularization. IL-8 expression is first observed in low grade astrocytoma in perivascular tumor areas expressing inflammatory cytokines. In HGGs, IL-8 further localizes in oxygen-deprived cells surrounding necrosis. Macrophages are known to produce high levels of IL-8, which has a tumorigenic activity, by inducing tumor growth and angiogenesis; IL-8 is an inflammatory chemoattractant responding to the tumor microenvironment. Tumor pseudopalisading cells secrete hypoxic inducing factor (HIF) which induces IL-8 secretion. These results support a model in which IL-8 expression, by induction of inflammatory stimuli, may be an early step in astrocytoma development. IL-8 expression later in tumor progression increases because of reduced microenvironmental oxygen pressure. It seems that augmented IL-8 directly and/or indirectly promotes angiogenesis by binding to DARC and induces leukocyte infiltration and activation by binding to CXCR1 and CXCR2. The contemporary actions of IL-8 into glioma angiogenesis and leukocyte infiltration, as well as macrophages, microglial cells and ECM components involvement, suggest IL-8 as a future interesting target in antitumoral antisense therapy. On the base of our preliminar results, we hypotize an important role of IL-8 as crucial angiogenesis mediator within HIF-1a pathway and crosstalk between hypoxia-induced high levels of HIF-1a and VEGF expression. To try to enhance an anti-angiogenic anti-tumoral effect an attractive therapeutic mechanism may be a selective antisense strategy against two molecular targets involved, at different lavels, in the same pathological pathway.

The nanoparticles-based delivery has emerged as a potential method to improve the efficacy of the existing detection and treatment options due to the non-toxicity and engineerability of nanoparticles. In gliomas treatment, the nanoparticle systems are designed to carry out other key functions, including shielding the active drug from producing systemic side effects, crossing the BBB, and targeting specific cells after his gained access to CNS (Caruso et al., 2010b).

Nanotechnology deals with structures and devices are emerging as a new field of research at the interface of science, engineering and medicine. This approach have the ability to carry antisense molecules, such as antisense oligonucleotides, short interfering RNA (siRNA) molecules and ribozymes, that, with different modalities, exert RNA interference on target gene expression after their internalization into the target tumor cells. Obviously more detailed researches about knowledge of cellular biology, and cancer biology will permit important progress in the implications of nanotechnology in cancer and naturally in malignant gliomas treatment. 
Glioma gene expression and its development during gliomagenesis will may help to better understand the role of important molecules involved in tumor-safe brain parenchyma relationships. These molecules, such as ECM proteases, cell adhesion molecules and their related signaling pathways show an important role in glioma cell migration and invasion and could be selectively attack to inhibits the glioma invasive rim. It is clear that the complexity and cross-talk between signal transduction pathways limits the potential efficacy of targeting a single receptor or molecule. Antisense targeted therapy is very fashinating and probably will be one of the most important strategy to treat high-grade glioma, into a multimodal approach for brain tumor treatment. The clinical results of this molecular approach are actually very poor, because of the relatively short time of application of this kind of strategy in brain tumors, the single molecular target chosen for targeted therapy and the anatomic and physiological barriers existing in CNS. Another important aspect to valuate is represented by the similarity between the overall survival and progression free survival in glioma patients treated according the standard protocol with surgery, chemotherapy and radiotherapy versus new experimental molecular multimodal protocol. These new future possible targeted antisense-based therapy have showed very interesting results in glioma cell lines and in in vivo murine models. On the base of these preliminar results and the limits of actual standard therapeutic protocol, we think that antisense therapy may be an interesting approach to modify the biological development of gliomas, probably trying to modulate crucial pathways of gliomagenesis during precocious steps of tumor progression and possibly two or more molecular targets of the same pathway or of two different pathways.

\section{References}

Andrews, DW, Resnicoff, M, Flanders, AE, Kenyon, L, Curtis, M, et al. (2001). Results of a pilot study involving the use of an antisense oligodeoxynucleotide directed against the insuline-like growth factor type I receptor in malignant astrocytomas. J Clin Oncol, Vol.19, No.8, (April 2001), pp. 2189-2200, ISSN 0732-183X.

Baker, BF, Condon, TP, Koller, E, McKay, Ra, Siwkowski, AM. (2001). Discovery and analysis of antisense oligonucleotide activity in cell culture. Methods, Vol.23, No.2, (February 2001), pp. 191-198, ISSN 0026-1270.

Bello, L, Francolini, M, Marthyn, P, Zhang, J, Carroll, RS, et al. (2001). Alpha(v)beta3 and alpha(v)beta5 integrin expression in glioma periphery. Neurosurgery, Vol.49, No.2 (August 2001), pp. 380-389, ISSN 0898-4921.

Caffo, M, Germanò, A, Caruso, G, Meli, F, Galatioto, S, et al. (2004). An immunohistochemical study of extracellular matrix proteins laminin, fibronectin and type IV collagen in paediatric glioblastoma multiforme. Acta Neurochir, Vol.146, No.10, (October 2004), pp. 1113-1118, ISSN 0139-3006.

Campbell, W, \& Pollack, IF. (1997). Growth factors in gliomas. Antisense and dominant negative mutant strategies. J Neurooncol, Vol.35, No.3, (December 1997), pp. 275285, ISSN 0167-594X.

Caruso, G, Caffo, M, Raudino, G, Alafaci, C, Salpietro, FM, et al. (2010a). Antisense oligonucleotides and extracellular matrix proteins: innovative therapeutic targets in the tratment of high grade gliomas. Recent Pat CNS Drug Discov, Vol.5, No.1, (January 2010), pp. 53-69, ISSN 1574-8898. 
Caruso, G, Raudino, G, Caffo, M, Alafaci, C, Granata, F, et al. (2010b). Nanotechnology platforms in diagnosis and treatment of primary brain tumors. Recent Pat Nanotechnol, Vol.4, No.2, (June 2010), pp. 119-124, ISSN 1872-2105.

Cech, TR \& Bass, BL. (1986). Biological catalysis by RNA. Ann Rev Biochem, Vol.55, (July 1986), pp. 599-629, ISSN 0066-4154.

Chen, G, Oh, S, Monia, BP, Stacey, DW. (1996). Antisense oligonucleotides demonstrate a dominant role of c-Ki-RAS proteins in regulating the proliferation of diploid human fibroblasts. J Biol Chem, Vol.271, No.45, (November 1996), pp. 28259-28265, ISSN 0021-9258.

Chu, S, Ma, Y, Feng, DF, Zhang, H, Qiu, JM, et al. (2010). C-Met antisense oligodeoxynucleotides increase sensitivity of human glioma cells to paclitaxel. Oncol Rep, Vol.24, No.1, (July 2010), pp. 189-194, ISSN 1791-2431.

Chu, S, Zhu, Z, Yuan, X, Li, Z, Jiang, P. (2006). In vitro and in vivo potentiating the cytotoxic effect of radiation on human U251 gliomas by the c-Met antisense oligodeoxynucleotides. J Neurooncol, Vol.80, No.2, (November 2006), pp. 143-149, ISSN 0167-594X.

Dean, NM, \& Bennett, CF. (2003). Antisense oligonucleotide-based therapeutics for cancer. Oncogene, Vol.22, No.56, (December 2003), pp. 9087-9096, ISSN 0950-9232.

El-Aneed, A (2004). Current strategies in cancer gene therapy. Eur J Pharmacol, Vol.498, No.1-3, (September 2004)pp. 1-8, ISSN 0014-2999.

Gladson, CL. (1999). The extracellular matrix of gliomas: modulation of cell function. J Neuropathol Exp Neurol, Vol.58, No.10, (October 1999), pp. 1029-1040, ISSN 00223069.

Gonzalez, J \& Gilbert, MR. (2005). Treatment of astrocytomas. Curr Opin Neurol, Vol.18, No.6, (December 2005), pp. 632-638, ISSN 1350-7540.

Grossman, SA, Alavi, JB, Supko, JG, Carson, KA, Priet, R, et al. (2004). Efficacy and toxicity of the antisense oligonucleotide aprinocarsen directed against protein kinase $C$ - $\square$ delivered as a 21-day continuous intravenous infusion in patients with recurrent high-grade astrocytomas. Neuro Oncol, Vol.7, No.1, (January 2004), pp. 32-40, ISSN 1523-5866.

Guensberg, P, Wacheck, V, Lucas, T, Monia, B, Pehamberger, H, et al. (2002). Bcl-xL antisense oligonucleotides chemosensitize human glioblastoma cells. Chemotherapy, Vol.48, No.4, (September 2002), pp. 189-195, ISSN 0009-3157.

Hanahan, D, \& Weinberg, RA. (2000). The hallmarks of cancer. Cell, Vol.100, No.1, (January 2000), pp. 57-70, ISSN 0092-8674.

Halatsch, ME, Schmidt, U, Behnke-Mursch, J, Unterberg, A, Rainer Wirtz, C. (2006). Epidermal growth factor receptor inhibition for the treatment of glioblastoma multiforme and other malignant brain tumors. Cancer Treat Rev, Vol.32, No.2, (April 2006), pp. 74-89, ISSN 0305-7372.

Hau, P, Jachimczak, P, Bogdahn, U. (2009). Treatment of malignant gliomas with TGF-beta2 antisense oligonucleotides. Expert Rev Anticancer Ther, Vol.9, No.11, (November 2009), pp. 1663-1674, ISSN 1473-7140.

Hau, P, Jachimczak, P, Schlingensiepen, R, Schulmeyer, F, Jauch, T, et al. (2007). Inhibition of TGFbeta2 with AP 12009 in recurrent malignant gliomas: From preclinical to phase I/II studies. Oligonucleotides, Vol.17, No.2, (Summer 2007), pp. 201-212, ISSN 15454576 . 
Holash, J, Maisonpierre, PC, Compton, D, Boland, P, Alexander, LR, et al. (1999). Vessel cooption, regression, and growth in tumors mediated by angiopoietins and VEGF. Science, Vol.284, No.5422, (June 1999), pp. 1994-1998, ISSN 0036-8075.

Holland, EC. (2001). Gliomagenesis: genetic alterations and mouse models. Nat Rev Genet, Vol.2, No.2, (February 2001), pp. 120-129, ISSN 1471-0056.

Idbaih, A, Ducray, F, Sierra del Rio, M, Hoang-Xuan, K, Delattre, JY. (2008). Therapeutic application of noncytotoxic molecular targeted therapy in gliomas: growth factor receptors and angiogenesis inhibitors. Oncologist, Vol.13, No.9, (September 2008), pp. 978-992, ISSN 1083-7159.

Im, SA, Gomez-Manzano, C, Fueyo, J, Liu, TJ, Ke, LD, et al. (1999). Antiangiogenesis treatment for gliomas: Transfer of antisense-vascular endothelial growth factor inhibits tumor growth in vivo. Cancer Res, Vol.59, No.4, (February 1999), pp. 895900, ISSN 1538-7445.

Immonen, A, Vapalathi, M, Tyynela, K, Hurskainen, H, Sandmair, A, et al. (2004). AdvHSVtk gene therapy with intravenous ganciclovir improves survival in human malignant glioma: a randomised, controlled study. Mol Ther, Vol.10, No.5, (November 2004), pp. 967-972, ISSN 1525-0016.

Iwado, E, Daido, S, Kondo, Y, Kondo, S. (2007). Combined effect of 2-5A-linked antisense against telomerase RNA and conventional therapies on human malignant glioma cells in vitro and in vivo. Int J Oncol, Vol.32, No.5, (November 2007), pp. 1087-1095, ISSN 1791-2423.

Izquierdo, M, Martin, V, de Felipe, P, Izquierdo, JM, Perez-Higueras, A, et al. (1996). Human malignant brain tumor response to herpes simplex thymidine kinase (HSVtk)/ganciclovir gene therapy. Gene Ther, Vol.3, No.6, (June 1996), pp. 491-495, ISSN 0969-7128.

Jachimczak, P, Hessdorfer, B, Fabel-Schulte, K, Wismeth, C, Brysch, W, et al. (1996). Transforming growth factor-beta mediated autocrine growth regulation of gliomas with phosphorothioate antisense oligonucleotides. Int J Cancer, Vol.65, No.3, (January 1996), pp. 332-337, ISSN 1097-0215.

Jain, RK, di Tomaso, E, Duda, DG, Loefflers, LB, Sorensen, AG, et al. (2007). Angiogenesis in brain tumours. Nat Rev Neurosci,Vol.8, No.8, (August 2007), pp. 610-622, ISSN 1471003X.

Jansen, B, \& Zangemeister-Wittke, U. (2002). Antisense therapy for cancer - the time of truth. Lancet Oncol, Vol.3, No.11, (November 2002), pp. 672-683, ISSN 1470-2045.

Jason, TLH, Koropatnick, J, \& Berg, RW. (2004). Toxicology of antisense therapeutics. Toxicology and Applied Pharmacology, Vol.201, No.1, (November 2004), pp. 66-83, ISSN 0041-008X.

Julien, T, Frankel, B, Longo, S, Kyle, M, Gibson, S, et al. (2000). Antisense-mediated inhibition of the bcl-2 gene induces apoptosis in human malignant glioma. Surg Neurol, Vol.53, No.4, (April 2000), pp. 360-369, ISSN 0090-3157.

Khazenzon, NM, Ljubimov, AV, Lakhter, AJ, Fujita, M, Fujiwara, H, et al. (2003). Antisense inhibition of laminin-8 expression reduces invasion of human gliomas in vitro. Mol Cancer Ther, Vol.2, No.10, (October 2003), pp. 985-994, ISSN 1538-8514.

Kohn, EC, \& Liotta, LA. (1995). Molecular insights into cancer invasion: Strategies for prevention and intervention. Cancer Res, Vol.55, No.2, (May 1995), pp. 1856-1862, ISSN 1538-7445. 
Kondo, S, Kondo, Y, Li, G, Silverman, RH, Cowell, JK. (1998). Targeted therapy of human malignant glioma in a mouse model by 2-5A antisense directed against telomerase RNA. Oncogene, Vol.16, No.25, (June 1998), pp. 3323-3330, ISSN 0950-9232.

Kondo, S, Tanaka, Y, Kondo, Y, Hitomi, M, Barnett, GH, et al. (1998). Antisense telomerase treatment: induction of two distinct pathways, apoptosis and differentiation. FASEB J, Vol.12, No.10, (July 1998), pp. 801-811, ISSN 0892-6638.

Komata, T, Kondo, Y, Koga, S, Lo, SC, Chung, LWK, et al. (2000). Combination therapy of malignant glioma cells with 2-5A-antisense telomerase RNA and recombinant adenovirus p53. Gene Ther, Vol.7, No.24, (December 2000), pp. 2071-2079, ISSN 0969-7128.

Liu, TJ, La Fortune, T, Honda, T, Ohmori, O, Hatakeyama, S, et al. (2007). Inhibition of both adhesion kinase and insulin-like growth factor-I receptor kinase suppresses glioma proliferation in vitro and in vivo. Mol Cancer Ther, Vol. 6, No.4, (April 2007), pp. 1357-1367, ISSN 1538-8514.

Ljubimova, JY, Fujita, M, Khazenzon, NM, Ljubimov, AV, Black, KL. (2006). Changes in laminin isoforms associated with brain tumor invasion and angiogenesis. Front Biosci, Vol.11, (January 2006), pp. 81-88, ISSN 1093-4715.

Macrae, IJ, Zhou, K, Li, F, Repic, A, Brooks, AN, et al. (2006). Structural basis for doublestranded RNA processing by Dicer". Science, Vol.311, No.5758, (January 2006), pp. 195-198, ISSN 0036-8075.

McKay, RA, Miraglia, LJ, Cummins, LL, Owens, SR, Sasmor, H, et al. (1999). A Characterization of a potent and specific class of antisense oligonucleotide inhibitor of human protein kinase C-a expression. J Biol Chem, Vol.274, No.3, (January 1999), pp. 1715-1722, ISSN 0021-9258.

Mohanam, S, Chintala, SK, Go, Y, Bhattacharya, A, Venkaiah, B. (1997). In vitro inhibition of human glioblastoma cell line invasiveness by antisense uPA receptor. Oncogene, Vol.14, No.11, (March 1997), pp. 1351-1359, ISSN 0950-9232.

Monia, BP, Sasmor, H, Johnston, J, Freier, SM, Lesnik, EA, et al. (1996). Sequence-specific antitumor activity of a phosphorothioate oligodeoxyribonucleotide targeted to human C-raf kinase supports an antisense mechanism of action in vivo. Proc Natl Acad Sci USA, Vol.93, No26, (December 1996), pp. 15481-15484, ISSN 1091-6490.

Mukai, S, Kondo, Y, Koga, S, Komata, T, Barna, BP, et al. (2000). 2-5A antisense telomerase RNA therapy for intracranial malignant gliomas. Cancer Res, Vol.60, No.16, (August 2000), pp. 4461-4467, ISSN 1538-7445.

Ohgaki, H, \& Kleihues, P. (2007). Genetic pathways to primary and secondary glioblastoma. Am J Pathol, Vol.170, No.5, (May 2007), pp. 1445-1453, ISSN 0887-8005.

Park, MJ, Kim, MS, Park, IC, Kang, KS, Yoo, H, et al. (2002). PTEN suppresses hyaluronic acid-induced matrix metalloproteinases-9 expression in U87MG glioblastoma cells through focal adhesion kinase dephosphrylation. Canc Res, Vol.62, No.21, (November 2002), pp. 6318-6322, ISSN 1538-7445.

Passioura, T, \& Symonds, G. (2004). Cancer gene suppression strategies: issues and potential. Curr Issues Mol Biol, Vol.6, No.2, (July 2004), pp. 89-102, ISSN 1467-3037.

Paterson, BM, Roberts, BE, \& Kuff, EL. (1977). Structural gene identification and mapping by DNA-mRNA hybrid arrested cell-free translation. Proc Nat Acad Sci, Vol.74, No.10, (October 1977), pp. 4370-4374, ISSN 1091-6490. 
Pirollo, KF, Rait, A, Sleers, LS, Chang, EH. (2003). Antisense therapeutics: from theory to clinical practice. Pharmacol Ther, Vol.99, No.1, (July 2003), pp. 55-77, ISSN 03276309.

Pollack, IF, Kawecki, S, \& Lazo, JS. Blocking of glioma proliferation in vitro and in vivo and potentiating the effects of BCNU and cisplatin: UCN-01, a selective protein kinase C inhibitor. J Neurosurg, Vol.84, No.6, (June 1996), pp. 1024-1032, ISSN 0022-3085.

Potapova, O, Gorospe, M, Dougherty, RH, Dean, NM, Gaarde, WA, et al. (2000). Inhibition of c-Jun N-terminal kinase 2 expression suppresses growth and induces apoptosis of human tumor cells in a p53-dependent manner. Mol Cell Biol, Vol.20, No.5, (March 2000), pp. 1713-1722, ISSN 1098-5549.

$\mathrm{Pu}, \mathrm{P}$, Kang, C, Li, J, Jiang, H, Cheng, J. (2006). The effects of antisense AKT2 RNA on the inhibition of malignant glioma cell growth in vitro and in vivo. J Neurooncol, Vol.76, No.1, (June 2006), pp. 1-11, ISSN 0167-594X.

Resnicoff, M, Sell, C, Rubini, M, Coppola, D, Sell, C, et al. (1994). Rat glioblastoma cells expressing an antisense RNA to the insuline-like growth factor-1 (IGF-1) receptor are nontumorigenic and induce regression of wild-type tumors. Cancer Res, Vol.54, No.8, (April 1994), pp. 2218-2222, ISSN 1538-7445.

Rubenstein, M, Mirochnik, Y, Chou, P, Guinan, P. (1996). Antisense oligonucleotides intralesional therapy for human PC-3 prostate tumors carried in athymic nude mice. J Surg Oncol, Vol.62, No.3, (July 1996), pp. 194-200, ISSN 1096-9098.

Schlingensiepen, R, Goldbrunner, M, Szyrach, MN, Stauder, G, Jachimczak, P, et al. (2005). Intracerebral and intrathecal infusion of the TGF- $\square$ 2-specific antisense phosphorotioate oligonucleotide AP 12009 in rabbits and primates: toxicology and safety. Oligonucleotides, Vol.15, No.2 (Summer 2005), pp. 94-104, ISSN 1545-4576.

Schlingensiepen, KH, Schlingensiepen, R, Steinbrecher, A, Hau, P, Bogdhan, U, et al. (2006). Targeted tumor therapy with the TGF- $\beta 2$ antisense compound AP 12009. Cytokine Growth Factor Rev, Vol.17, No.1-2, (February-April 2006), pp. 129-139, ISSN 13596101.

Schneider, T, Becker, A, Ringe, K, Reinhold, A, Firscing, R, et al. (2008). Brain tumor therapy by combined vaccination and antisense oligonucleotide delivery with nanoparticles. J Neuroimmunol, Vol.195, No.1-2, (March 2008), pp. 21-27, ISSN 01655728.

Semenza, GL. (2003). Targeting HIF-1 for cancer therapy. Nat Rev Cancer, Vol.3, No.10, (October 2003), pp. 721-732, ISSN 1474-175X.

Smythe, WR, Mohuiddin, I, Ozveran, M, Cao, XX. (2002). Antisense therapy for malignant mesothelioma with oligonucleotides targeting the bcl-xl gene product. J Thorac Cardiovasc Surg, Vol.123, No.6, (June 2002), pp. 1191-1198, ISSN 0022-5223.

Stegh, AH, Kim, H, Bachoo, RM, Forloney, KL, Zhang, J, et al. (2007). Bcl2L12 inhibits postmitochondrial apoptosis signaling in glioblastoma. Genes Dev, Vol.21, No.1, (January 2007), pp. 98-111, ISSN 0890-9369.

Stephenson, ML, \& Zamecnik, PC. (1978). Inhibition of Rous sarcoma virus replication and cell transformation by a specific oligodeoxynucleotide. Proc Nati Acad Sci, Vol.75, No.1, (January 1978), pp. 280-284, ISSN 1091-6490.

Stupp, R, Mason, WP, van den Bent, MJ, Weller, M, Taphoorn, MJ, et al. (2005). Radiotherapy plus concomitant and adjuvant temozolamide for glioblastoma. $N$ Engl J Med, Vol.352, No.10, (March 2005), pp. 987-996, ISSN 0028-4793. 
Tamm, I. (2006). Antisense therapy in malignant disease: status quo and quo vadis? Clin Sci, Vol.110, No.4, (April 2006), pp. 427-442, ISSN 0143-5221.

Wacheck, V, \& Zangemeister-Wittke, U. (2006). Anisense molecules for targeted cancer therapy. Oncol Hematol, Vol.59, No.1, (July 2006), pp. 65-73, ISSN 1536-3678.

Wesseling, P, \& Adema, GJ. (2009). Immunotherapy of diffuse gliomas: helping the brain fight back!. Brain Pathology, Vol.19, No.4, (October 2009), pp. 674-693, ISSN 17503639.

Whitesell, L, Rosolen, A, \& Neckers, LM. (1991). In vivo modulation of Nmyc expression by continuous perfusion with an antisense oligonucleotide. Antisense Res Dev, Vol.1, No.4, (Winter 1991), pp. 343-350, ISSN 1050-5261.

$\mathrm{Wu}, \mathrm{ZM}$, Yuan, XH, Jiang, PC, Li, ZQ, Wu, T. (2006). Antisense oligonucleodes targeting the focal adhesion kinase inhibit proliferation, induce apoptosis and cooperate with cytotoxic drugs in human glioma cells. J Neurooncol, Vol.77, No,2, (April 2006), pp. 117-123, ISSN 0167-594X.

Yancopoulos, GD, Davis, S, Gale, NW, Rudge, JS, Wiegand, SJ, et al. (2000). Vascular-specific growth factors and blood vessel formation. Nature, Vol.407, No.6801, (September 2000), pp. 242-248, ISSN 0028-0836.

Zadeh, G, Qian, B, Okhowat, A, Sabha, N, Kontos, CD, et al. (2004). Targeting the Tie2/Tek receptor in astrocytomas. Am J Pathol, Vol.164, No.2, (February 2004), pp. 467-476, ISSN 0887-8005.

Zagzag, D, Amirnovin, R, greco, MA, Yee, H, Holash, J, et al. (2000). Vascular apoptosis and involution in gliomas precede neovascularization: a novel concept for glioma growth and angiogenesis. Lab Invest, Vol.80, No.6, (June 2000), pp. 837-849, ISSN 0023-6837.

Zhou, X, Zhang, J, Jia, Q, Ren, Y, Wang, Y, et al. (2010). Reduction of miR-21 induces glioma cell apoptosis via activating caspase 9 and 3. Oncol Rep, Vol. 24, No.1, (July 2010), pp. 195-201, ISSN 1791-2431. 


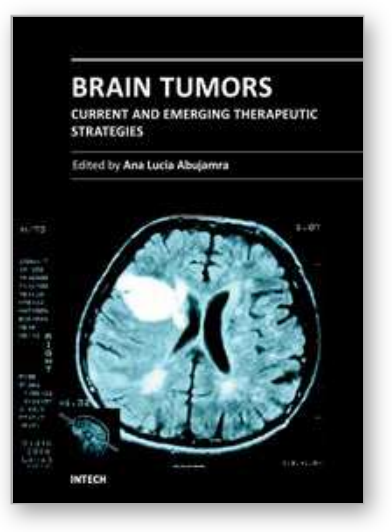

\author{
Brain Tumors - Current and Emerging Therapeutic Strategies \\ Edited by Dr. Ana Lucia Abujamra
}

ISBN 978-953-307-588-4

Hard cover, 422 pages

Publisher InTech

Published online 23, August, 2011

Published in print edition August, 2011

Brain Tumors: Current and Emerging Therapeutic Strategies focuses on tumor models, the molecular mechanisms involved in the pathogenesis of this disease, and on the new diagnostic and treatment strategies utilized to stage and treat this malignancy. A special section on immunotherapy and gene therapy provides the most up-to-date information on the pre-clinical and clinical advances of this therapeutic venue. Each chapter in Brain Tumors: Current and Emerging Therapeutic Strategies is authored by international experts with extensive experience in the areas covered.

\title{
How to reference
}

In order to correctly reference this scholarly work, feel free to copy and paste the following:

Gerardo Caruso, Mariella Caffo, Giuseppe Raudino, Concetta Alafaci and Francesco Tomasello (2011). New Therapeutic Strategies in Gliomas Treatment, Brain Tumors - Current and Emerging Therapeutic Strategies, Dr. Ana Lucia Abujamra (Ed.), ISBN: 978-953-307-588-4, InTech, Available from:

http://www.intechopen.com/books/brain-tumors-current-and-emerging-therapeutic-strategies/new-therapeuticstrategies-in-gliomas-treatment

\section{INTECH}

open science | open minds

\section{InTech Europe}

University Campus STeP Ri

Slavka Krautzeka 83/A

51000 Rijeka, Croatia

Phone: +385 (51) 770447

Fax: +385 (51) 686166

www.intechopen.com

\section{InTech China}

Unit 405, Office Block, Hotel Equatorial Shanghai

No.65, Yan An Road (West), Shanghai, 200040, China 中国上海市延安西路65号上海国际贵都大饭店办公楼 405 单元

Phone: +86-21-62489820

Fax: +86-21-62489821 
(C) 2011 The Author(s). Licensee IntechOpen. This chapter is distributed under the terms of the Creative Commons Attribution-NonCommercialShareAlike-3.0 License, which permits use, distribution and reproduction for non-commercial purposes, provided the original is properly cited and derivative works building on this content are distributed under the same license. 